\title{
NANOTECHNOLOGY FOR ACHIEVING GREEN-ECONOMY THROUGH SUSTAINABLE ENERGY
}

\author{
Garima Pandey \\ Department of Chemistry, SRM-IST,Delhi-NCR Campus,Ghaziabad \\ E-mail: garimapandey.pandey8@gmail.com
}

\begin{abstract}
Mankind is struggling with so many problems related to an environment like pollution, energy demand and supply, soil security, availability of food etc. The pollution caused because of the improper management of natural resources is raising serious concerns towards environment safety and sustainability. Chemistry plays a fundamental role in the sustainability of environment by promoting green technologies and advances in new and less or nonhazardous materials for industries, generating and promoting sources for renewable energy ,environmental protection. Keeping in mind the demand of energy for all the developmental processes, it is very much necessary to promote the production and consumption of sustainable energy, in turn, boosting green economy. For encouraging a green economy it is necessary to find new ways of producing green energy by using nanoparticles. This review will focus on the evaluation of the green nanochemistry for sustainable development and will highlight new advances in the green economy by using nanomaterials
\end{abstract}

Keywords: Hazardous, Green chemistry, nanomaterials, Sustainable

(C) RASĀYAN. All rights reserved

\section{INTRODUCTION}

The worldwide industrial and technical boom in the current century has made scientists rethink about the about relation between socio-economic growth and environmental ethics and it's been realized that for the existence of the future generations of human civilization it is the call of the hour to adapt to sustainable management of natural resources. The concept of sustainability was first introduced in the year 1987 through a report by the World Commission on Environment and Development of the United Nations ${ }^{1}$ by stating, that the further existence of future generations of mankind and, the accomplishment of social and monetary requirements of current population can be made possible only, if, the natural assets are managed appropriately and the rapport between economic-growth and compassion towards the environment of the current and upcoming generations is judicially managed, while assessing and managing the long-term effects of industrial activities . Environmental pollution is most life-threatening global issues ${ }^{2}$ and is being reflected everywhere in the land, water,and air. These environmental pollutions develop a kind of abiotic stress on the environment. As per WHO air pollution ${ }^{3}$ along with soil and water pollution is the major concern acting as a serious threat to human health. Although all the pollutants, be it organic or inorganic are a threat to the environment but the most important and difficult ones for the current century are electronic wastes $^{4,5}$, pharmaceutical pollutants ${ }^{6,7}$, volatile organic compounds $^{8-12}$ heavy metals and nano-pollutants ${ }^{13,14}$. Therefore new technologies should be developed and promoted to notice, detect and remove all these hazardous environmental contaminants ${ }^{15,16}$. With every passing year a considerable increase in the quantity of these pollutants is being observed by the scientists ${ }^{17,18}$. The worldwide production, consumption and trading of chemicals play a fundamental role in shaping the future of sustainable development. Since very beginning chemists are trying to identify their share of responsibility towards the goal of sustainability. Since 1990 American Chemical Society (ACS) is promoting the strategies supporting sustainable technologies using the principle of green chemistry, and green engineering. Nanotechnologies have shown to have significant effects on creating 'clean' and 'green' methods with substantial environmental remunerations.

Rasayan J. Chem., 11(3), 942-950(2018)

http://dx.doi.org/10.31788/RJC.2018.1133031

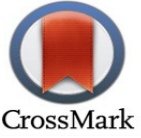


The thought of coupling green-nanotechnology intends to develop and use nanotechnology facilitated innovations in material-science and engineering-technology to create environment-friendly and economically sustainable as well as energy efficient routes and products for strengthening the economicsector, through modifications in the methods of producing and storing energy, redesigning construction industries and clean-up technologies. All these efforts might create new prospects for reducing the burden on conventional energy working on the options of renewable-energy creating an enhanced ecosystem and better occupation conditions boosting the green economy. This paper analyses the effects, challenges and opportunities of nano-technology in establishing and practicing the green economy principles such as maintaining the sustainability while fulfilling the global energy demands, safety and health impact of green nanotechnology.

\section{Sustainability through Energy: Energy Resources and Consumption of Energy}

The current pace of energy consumption is increasing the pressure on natural resources and fossil fuels and it is being expected that with the current pace the annual consumption of energy will get doubled of the current demand ${ }^{19}$ up to the year 2050. Although the demand for energy is fulfilled mostly from fossil fuels which in turn emit toxic gases leading to major natural disasters and climatic changes. To combat this side effect of fossil energy researchers all around the world are trying to find safe and eco-friendly key alternatives to non-renewable fossil fuels. Solar energy is the plentiful resource which is freely available globally. The challenge is to identify and develop practically efficient technologies to yield and store the solar energy ${ }^{20}$. One such method is the use of solar panels and solar cells for the production, storing and converting the solar energy. It is been established through research that nanotechnology can be used as an alternative to the non-renewable conventional energy resources and is a tool to achieve the vision of Hydrogen economy ${ }^{21}$. Wind energy is used to generate electricity using wind turbines. These turbines use generators for converting mechanical energy into electrical energy. Nanotechnology can play an important role to make these turbines cost-effective and light-weight. Use of carbon nanotubes in turbines makes rotor blades light in weight and increases the conductivity and strength of the blades ${ }^{22}$. Application of nanotechnology in the energy sector leads to the production of more efficient, economically cheaper and environment-friendly energy production leading to a path of sustainability. The future of energy holds the use of nanostructures to produce low on fuel and lightweight hybrid vehicles ${ }^{23}$.

\section{Green Economy and Nanotechnology}

The concept of green economy had come into the debate to address global challenges and issues in areas such as changes in the environment, ever increasing energy demand, and health concerns ${ }^{24-26}$. Green economy as a term was first coined in 1989 by a group of environmental economists of Government of the $\mathrm{UK}^{27}$. Green economy is the concept based on the principles of sustainable development and has a very broad meaning and includes the processes based on the principles of appreciating social and natural capital, consistency in environmental sustainability, maintaining the socio-ecological balance, green accounting resulting into improvement of human well-being by creating green jobs for people, increasing competitiveness, environmental responsibility, poverty eradication and overall growth in key sectors ${ }^{28-}$ ${ }^{32}$. This includes processes, actions, aims and principles which are socially comprehensive, source competent and low in carbon. The concept of green-economy might have a substantial responsibility in balancing the interaction of economic and environmental spheres creating more employment opportunities as green-jobs, efficient and judicial resource management, by increasing the growth in key economic sectors through consistent sustainable approach and nanotechnology comes up with new and innovative green methods of producing innovative devices and materials with specific physical and chemical properties, which are economically and environmentally sustainable ${ }^{33-37}$. The theory of greeneconomy is characterized either by a substantial boost in investments and new ventures in economic sectors leading to improvement and reinforcement in the natural wealth of the Earth or contributions towards diminishing the threats and deficiencies in environmental sectors. In-particular efforts are being made for sustainable energy, green-constructions, clean-technologies, low emission transport techniques, waste management and sustainable agriculture. With no doubt, out of all these sectors, it's the energy sector which plays a major role as an energy source, consumption and management is the key to all the 
RASĀYAN J. Chem.

Vol. 11 | No. 3 |942 - 950 | July - September | 2018

economic developments and for this, the concept of using sustainable energy is highly being promoted. Sustainable energy asks for the innovations, acceptance and marketing of the model of a green economy for a more ample and integrated approach to the fit-in environment in economic theories. It is being expected that nanomaterials will have a huge influence on industries and on economic sectors. Nanotechnology aims to discover potential ways to enhance economic growth keeping in-mind environmental and ecological issues and contributing towards reducing threats to natural-resources, mostly through energy-efficient innovations. The benefits of using nanostructures for sustainable growth have to struggle with market and industry acceptance ambiguity, competition with the long-established conventional technologies along with some environmental safety risks and health hazards ${ }^{38}$.

\section{Green Nanotechnology}

In the year 1991 Paul Anastas, under the U.S. Environmental Protection Agency program communicated the term Green Chemistry (4-8). Since then green chemistry is playing the role of an important element for improving standards of living and leading to greater protection of health and the environment through chemicals management ${ }^{39}$. It is a broad concept but is most frequently associated with efforts of hazard reduction. US EPA states that green chemistry, "applies across the life cycle of a chemical product, including its design, manufacture, use, and ultimate disposal" 40 . The key to green chemistry is the concept of fewer hazards. and less hazardous chemicals are being defined as substances those have a less damaging effect on the environment, are less in toxicity towards organisms, are not persistent in nature, and are safer to use $\mathrm{e}^{41}$.Green chemistry is the eco-friendly route of producing materials with reduced consumption and production of hazardous substances by using biodegradable, environmentally safe materials. In the year 2014, the UNEA, recognized a new term, sustainable chemistry. Green chemistry is well defined and it's been more than 20 years that it is been recognized as a formal sub-discipline of chemistry "Green Nanotechnology" is a new area of designing new products that are benign to human and environmental health. This green synthesis is potentially transforming the fate of synthesizing nanoparticles ${ }^{42}$ and is benefiting future applications of nanotechnology. This new concept along with the basics of green chemistry is benefitting and setting new standards for producing clean and sustainable nanomaterials. Scientists have reported green methods synthesis of nanoparticles from plants and microorganisms ${ }^{43}$. Although green nanotechnology shows a bright picture of clean, eco-friendly safer nanotechnology still it has the challenge to deal with the toxic effects of nanoparticles on the environment and health aspects. Nanomaterials from green synthesis have reported having vast applications in energy storage, nanosensing and nanomedicine ${ }^{44,45}$ but the challenges and issues related to toxicological effect, unclear production and safety guidelines with green nanotechnology need further analysis and assessment ${ }^{46}$. Green nanotechnology is in its nascent phase and still has a long way to go to change the path of conventional methods towards greener approach and strategies for its industrial. Further analysis of more understanding of fundamental reaction mechanisms of green synthesis, appropriate and accurate characterization methods will build a concrete ground for environment-friendly, cost-effective and sustainable nanotechnology via green synthesis.

\section{Nanotechnology in Energy}

Break-through in nano-technology could offer new technologies to contribute towards global energysecurity and energy-supply. As per the report by Rice University (Texas,2005), several areas were recognized, in the which nanotechnology can initiate in-expensive, efficient, and environment-friendly technologies ${ }^{47}$. The advantages of nano-technology are being acknowledged in various domains, involving solar-energy, wind-energy, fusion-reactors, clean-coal, fission-reactors, hydrogen-production, storage and shipping and transportation, fuel cells and batteries. The major areas where nano-technology have a say are-

i. Lowering the cost of solar photovoltaic cell the s and solar cells

ii. Commercializing photoconversion of water and light to generate hydrogen along with the photo-catalytic reduction of carbon dioxide to methanol,

iii. Improving the storage-capacity and power-efficiency of super-capacitors and batteries. 
RASĀYAN J. Chem.

iv. Creating light-weight materials for hydrogen-storage for reversible chemisorption, liquid hydrogen-vessel and pressure-tanks.

v. Developing nano-based quantum conductors, power-cables, super-conductors to decrease or remove current-loss and thermal drops and redesigning long-distant,the transportation of electrical energy.

vi. Developing nano-coatings to facilitate cost-effective drilling of geothermal energy

Though achieving these targets completely will take a very long time but industry and academic research institutes are putting in their best efforts to explore and exploit all the possibilities. The discovery of nano-grass by the scientists from Bell Labs has made them investigate and assess the chances of creating a micro-battery with a 20 years life. Scientists from all over the world are very optimistic about completely dispensing with batteries by designing nano-tubes based ultra-capacitors which are adequate powerful to push hybrid electric cars. These ultra-capacitors have a longer life, more power to weight ratio, can perform well under extreme temperature conditions and get charged within seconds. Though this technology is in its primitive stage and most of the developments are confined to developed countries still it is being predicted that the global market of ultra-capacitors would increase manifolds in the coming years. One more area in which nanotechnology is already being recognized significantly is the Photovoltaics and start-ups from all over the world are producing cost-effective photon-harvesting articles as compared to conventional silicon photovoltaic cells. It is observed that the use of nanotech solar fabric on the top of bridges and buildings would improve their energy-landscape potentially. When incorporated into the top of a vehicle like a truck or a bus, these nano-based solar fabrics may lead to water-splitting through electrolysis and produce hydrogen fuel. It is expected that NT will play an elemental role in improving the key functionalities of a product, both through utilizing the positive attributes of nanotechnology by including nanoparticles in devices, as well as by using nano-applications and principles in devices ${ }^{48.49}$ though majority of the green nano-based solutions and options are still in very primitive stage of production, acceptance and marketing, Further research and studies are needed to review the sustainability, competence and applicability of nano-solutions under more pragmatic and broader perspectives. The distinctive features of nanomaterials make them useful as electrolytes and electrodes in electrochemical sensing, energy harvesting, energy storing devices ${ }^{50,51}$. In the last few years, the perspective of nanoparticles for generating the innovative and sustainable energy solutions and applications is being highly explored. Metal-oxide nanomaterials e.g. $\mathrm{ZnO}$ nanomaterials have shown promising potential to be used in piezoelectric devices1 for converting mechanical energy into electrical energy $^{52}$. Nanowires made up of $\mathrm{ZnO}$ nanomaterial ${ }^{53}$ are being used for making handwriting enabled nanogenerators for the harvesting of electricenergy ${ }^{54}$. Some metal oxide like $\mathrm{TiO} 2^{55}$ and $\mathrm{Cd}$ - sulfide nanoarticles have very strong catalytic property ${ }^{56}$ which can be highly useful for fabricating cost-effective photoelectrodes used in the production of hydrogen from water splitting ${ }^{57}$. The nano-size structures in photovoltaic ${ }^{58,59}$ cells increase the area of exposure of conducting surfaces which enhances the collection of solar energy. The use of mesoporous nanostructures ${ }^{60}$ like quantum dots, carbon nanotubes and fullerenes in solar cells makes them cheaper, lighter and increases their efficiency, electrical conductivity, mechanical strength, durability and corrosion resistance ${ }^{61-63}$. Use of lead-selenide ${ }^{64}$ in photovoltaic cells increases their efficiency by increasing the number of electrons released per photon. Nanostructures have potential applications as multifunctional power sources for making soft and wearable electronics ${ }^{65}$.The development of nanogenerators creates a possibility of letting the electronic devices be operated by the ambient energy harvested from the environment. The current developments in the area of nanogenerators will pave the way for future energy sensing technologies by laying the foundation for autonomous systems. Triboelectric nanogenerators $(\mathrm{TENG})^{66-68}$ and skin-like triboelectric nanogenerator (STENG) ${ }^{69}$, ${ }^{70}$ convert mechanical energy into electrical energy enabling biomechanical energy harvesting. The two main members of the nanogenerator family used for harvesting mechanical energy from the environment are piezoelectric NG (PENG) ${ }^{71}$ and triboelectric NG (TENG ${ }^{72}$. Out of these two TENG has been proved to be very promising for harvesting mechanical energy from water ${ }^{73-76}$ wind $^{77,} 78$ motion of humans ${ }^{79-}$ ${ }^{81}$. The outstanding energy harvesting capabilities of both PENG and TENG have garnered worldwide attention from researchers and industries. Further research and innovations of NGs will mark the 
RASĀYAN J. Chem.

Vol. 11 | No. 3 |942 - 950 | July - September | 2018

development of self-powered systems which will lead to a promising future of energy and sensing technology. For harvesting, the widespread thermal energy of environment scientists have produced ${ }^{81}$ pyroelectric NG and thermoelectric NG (PyENG and ThENG)

The potential applications of NT for energy sector can be summarized are the following points:

\section{Nanomaterials for Energy Conversion and Storage}

The nano-structured articles are fascinating energy sector due to their unique property to influence the amount of light and control the energy flow at nanoscales on the atomic level ${ }^{83,84}$. Use of nano principles and structures in energy sector helps achieve green economy by decreasing the usage of raw materials, by increasing the efficiency, life-cycle and stability of the cells,Most of the next-gensolar-powered batteries used for converting sun energy into mechanical, chemical, or electrical energy ${ }^{85-88}$ are based on nanostructured materials like nanowires, mesoscopic nano-structures, quantum dot cells etc. ${ }^{89}$, ${ }^{90}$.One of major fascinating and supple conventional energy methods is the photovoltaic effect, directly converting solar energy to electrical energy and recent developments in the area of nanotechnology have opened new horizons for accelerating the electrical outputs of photovoltaic cells. Though the efficiency of these cells is not enough when compared with silicon solar-cells still the use of quantum dot nanostructures improves their efficiency because their wide band-gap makes them absorb a broad spectrum of EMR.CNMs like C60-fullerenes ${ }^{91,92}$ graphenes and ${ }^{93,}{ }^{94} \mathrm{C}$-nanotubes ${ }^{95,}{ }^{96}$ have been found to be tremendously competent electron acceptors for use in quantum dot and polymer solar cells ${ }^{97}$. The energy conversion and transfer efficiency of dye-sensitized solar cells can be improved by using nano-crystalline film of charge transfer dye coated mesoporous $\mathrm{TiO} 2$ (titanium dioxide) on a transparent charge conducting substrate ${ }^{73-76}$. The affluent surface chemistry, large surface area, and low specific-densities of nanoporous metallic make them extremely useful as very proficient electro-catalysts in fuel cells ${ }^{80,81}$.Though platinum nanoparticles based electrodes show carbon mono-oxide deactivation and sometimes dependent drifting nature, still the great resistance and higher electro-catalytic activities of ${ }^{97,98}$ nanosized bi and trimetallic alloys of platinum have shown promising results as good cell catalyst ${ }^{99}$. While the new generation photovoltaic cells like polymer cells, multi-junction solar cells, thin-film chalco-genides, hybrid perovskites, quantum dot-based solar cells have shown promising future of green economy still, to make them broadly accepted and marketed, there are many issues that need to be addressed and resolved. The distribution of electrical energy generated from renewable resources requires proper storage mediums ranging from huge public efficacies to pocket-sized handy electronic machines which are being achieved by using batteries as a chemical medium of storage or electrical capacitors as capacitive storage ${ }^{100,101}$. The larger surface area and compact dimensions of nanostructures improve the storage and release of energy, provides stability to the electrodes against the damage induces by ion intake and offers adequate fracture resistance and strain relaxation to the electronic devices and ${ }^{97}$ improves the rate of electron flow by improving the electrode electrolyte contact. Nanotechnology can play an effective role in persuading new and innovative storage techniques for electrical energy ${ }^{98}$ like nanostructure-based redox super capacitors .On a laboratory scale, these nano-based electrodes have shown to have immense potential of combining the high power density of traditional cells with the high energy potential of electro-static capacitors. The use of nanostructures of oxides of metals such as ruthenium, manganese ,tin titanium and iron ${ }^{100,101}$ along-with grapheme $^{102,103}$ silicon nano-wires ${ }^{104}$ and carbo-metal composites ${ }^{105}$ have shown to be high in speed $^{100,101}$ and specific capacity when investigated as electrode ${ }^{102,103}$.Nano-composites are being used innumerous applications for the purpose of energy-harvesting and energy-storage market. The key reason behind this is their characteristic property of providing cost-effective semi-conductors and appreciable energy storage ${ }^{106,}{ }^{107}$.Nano-composites are used in thin-film and flexible energy-storage devices such as asLi-ion batteries,hybrid devices and super-capacitors ${ }^{107}$ Nano-composites like TiO2 -Gold composite is also being used for semi-conductor assisted photo-catalysis for hydrogen fuel production ${ }^{108}$.

\section{CONCLUSION}

Green chemistry along with green nano-technology is intended to create energy competent, environmentfriendly and economically sustainable applications of nanomaterials for achieving a green economy. It is expected that these innovations will contribute towards reducing the pressure on non-renewable energy 
RASĀYAN $J$. Chem.

Vol. 11 | No. 3 |942 - 950 | July - September | 2018

sources. The unique chemical and physical properties of NMs might produce undesirable effects of the people having long-term exposure to them, therefore it is very much necessary to do proper assessment and management of the risk factors through research and technological analysis.This will offer fruitful information and directions to take-up appropriate precautionary measures for an overall hazard management. On the whole green nano-technology must not only offer green options and solutions, it should also pay attention towards occupational health security to make them get widely accepted, adopted and marketed to generate the green economy. This watchful contemplation will get most of the environmental, sociological and economic benefits, and will amplify the probability of involvement of additional investments and sustainable expansion of this potential technology.

\section{REFERENCES}

1. Z.L. Wang and J. Song, Science, 312(5771), 242(2006), DOI: 10.1126/science.1124005

2. F.-R. Fan, Z.-Q. Tian, and Z. L. Wang, Nano Energy, 1(2), 328(2012), DOI:10.1016

3. Y. Yang, W. Guo, K. C. Pradel, G. Zhu, Y. Zhou, Y. Zhang, Y. Hu, L. Lin, and Z. L. Wang, Nano Lett.,12(6), 2833 (2012), DOI: 10.1021/nl3003039

4. Y. Zi1 and Z. L.Wang, APL Materials 5, 074103 (2017), DOI: 10.1063/1.4977208

5. C. Allen, S. Clouth, A Guidebook to the Green Economy. Issue 1: Green Economy, Green Growth, and Low-Carbon Development-History, Definitions and a Guide to Recent Publications, UN Division for Sustainable Development UNDESA, (2012).

6. E. B. Barbier, Natural Resources Forum, 35(3), 233(2009), DOI: org/10.1111/j.14778947.2011.01397.x.

7. F. Caprotti, I. Bailey, Human Geography, 96(3), 195(2014), DOI:10.1111/geob.12045

8. A. Volkery, S. Rouabhi, Green Economy, Discussion Paper, UNEP, IEEP, GLOBE-EU. [Retrieved,2015-11-03] (2015), http://www.unep.org/research4policy/ policybriefs/tabid/78428/ Default.aspx

9. X. Wang, G. I. Koleilat, J. Tang, H. Liu, I.J. Kramer, and R. Debnath, Nat. Photonics, 5, 480(2011), DOI:10.1038/nphoton.2011.123

10. I. Thomann, B. A. Pinaud, Z. Chen, B. M. Clemens, T. F. Jaramillo, and M. L. Brongersma, Nano Lett.,11, 3440(2011), DOI:10.1021/n1201908s

11. Y. Sun, N. Liu, and Y. Cui. Nat. Energy, 1(7),16071 (2016), DOI: 10.1038/nenergy.2016.71

12. F. Lin, I. M. Markus, D. Nordlund, T. C. Weng, M. D. Asta, and H. L. Xin, Nat. Commun., 5, 3529(2014), DOI:10.1038/ncomms4529

13. Economic Commission for Latin America and the Caribbean: A Green Economy: Introduction To The Debate And Implications for Latin America and Caribbean. In 2010.http://www.cepal.org/dmaah/noticias/ticias/4/41684/DraftDiscussionPaper.pdf

14. Organisation for Economic Co-operation and Development: Interim Report of the Green Growth Strategy: Implementing Our Commitment for a Sustainable Future. In; 2010. http://www.oecd.org/greengrowth/45312720.pdf

15. D.S. Yu, E. Nagelli, F. Du, L.M. Dai, and J. Phis,Chem Let.t.,1, 2165(2010), DOI: 10.1021/jz100533t

16. X. Zhao, B.M. Sánchez, P.J. Dobson, and P.S. Grant, Nanoscale,3, 839(2011), DOI: 10.1039/c0nr00594k

17. T.Y. Kim, H.W. Lee, M. Stoller, D.R. Dreyer, C.W. Bielawski, R.S. Ruoff, and K.S. Suh, ACS Nano., 5, 436( 2011), DOI: 10.1021/nn101968p

18. P. R. Somani, S. P. Somani, E. Flahaut, and M. Umeno, Nanotechnology,18,185708(2007), DOI: org/10.1088/0957-4484/18/18/185708

19. C. Ampelli, S. Perathoner and G. Centi, Chinese J. Catal., 35(6), 783(2014), DOI: 10.1016/S18722067(14)60139-X

20. D. S. Su, S. Perathoner, and G. Centi, Chem Rev., 113(8), 5782(2013), DOI: 10.1021/cr300367d

21. M. M. Titirici, R. J. While, N. Brun, V. L. Budarin and D.S. Su, Chem. Soc. Rev.,44(1), 250(2015), DOI: $10.1039 / \mathrm{c} 4 \mathrm{cs} 00232 \mathrm{f} . \mathrm{s}$

22. Applications of nanotechnolgy in energy sector by Hessen nanotech, Hessen Germany, www.hessennanotech.de. 
RASĀYAN J. Chem.

Vol. 11 | No. 3 |942 - 950 | July - September | 2018

23. Alternative Energy \& Nanotechnology by Grant E Gardner, PCOST

24. A. Demirbas, $1^{\text {st }}$ Ed., Springer, London, UK, pp. 231-260( 2009).

25. N. Gaurav, S. Sivasankari, G.S. Kiran, A. Ninawea, and J. Selvin, Renew. Sustain. Energy Rev., 73, 205(2017), DOI: 10.1016/j.rser.2017.01.070

26. D.G. Olson, J.E. McBride, A.J. Shaw, and L.R. Lynd, Curr. Opin. Biotechnol, 23, 396 (2012), DOI: 10.1016/j.copbio.2011.11.026

27. D. Chung, M. Cha, A.M. Guss, and J. Westpheling, Proc. Natl. Acad. Sci. USA,111, 8931(2014), DOI: 10.1073/pnas.1402210111

28. J. Zhang, Z. Xia, and L. Dai, Sci. Adv.,1, e1500564,( 2015), DOI: 10.1126/sciadv.1500564

29. S. Cosnier, M. Holzinger, and A.L. Goff, Front. Bioeng. Biotechnol., 2,(2014), DOI: 10.3389/fbioe.2014.00045

30. L. Sizhe, H. Yongyou, X., Qian, S. Jian, H. Bin, and Z. Yaping, J. Power Sour., 213, 265(2012), DOI: 10.1016/j.jpowsour.2012.04.002

31. G.G. Kumar, C.J. Kirubaharan, D.J. Yoo, and A.R. Kim, Int. J. Hydrogen Energy, 41, 13208(2016), DOI: 10.1016/j.ijhydene.2016.05.099

32. M. Ghasemi, W.R.W. Daud, S.H.A. Hassan, T. Jafary, M. Rahimnejad, A. Ahmad and M.H. Yazdi, Int. J. Hydrogen Energy, 41, 4872(2016), DOI:10.1016/j.ijhydene.2015.09.011

33. F. Caprotti, I. Bailey and G. Annaler, Series B, Human Geography, 96(3), 195(2014), DOI:10.1111/geob.12045

34. E. B. Barbier, Natural Resources Forum, 35(3), 233(2011), DOI:10.1111/j.1477-8947.2011.01397.x.

35. A. Hamdouch, and M. H. Depret, J. of Env. Planning and Management, 53(4), 473(2010), DOI:10.1080/09640561003703889

36. UNEP,Availableat:http://www.unep.org/greeneconomy/Portals/88/documents/ger/ger_final_dec_201 1/Green\%20EconomyReport,Final(2011).

37. J. P. Spets, Y. Kiros, M.A. Kuosa, J. Rantanen, J. Sallinen, M.J. Lampinen, and K. Saari, Open Fuel Cells J., 1, 1(2008), DOI: 10.2174/1875932700801010001

38. A. Singh, P.S. Nigam, and J.D. Murphy, Bioresour. Technol.,102,10(2011), DOI: 10.1016/j.biortech.2010.06.032

39. A. Hagfeldt, G. Boschloo, L.Sun, L. Kloo, and H. Pettersson, Chem Rev., 110, 6595 DOI: $10.1021 / \mathrm{cr} 900356 \mathrm{p} \backslash$

40. N. Kheirabadi, and A. Shafiekhani, J. of App. Phy., 112, 124323 (2012), DOI:10.1063/1.4771923

41. Z. Wang, Land Zhou, X. W. Lou, Adv Mater, 24, 1903(2012).

42. J. Zhang,G. Zhang, M. Qi, H. Hu and X.Ma, Chemical Papers, 72, 273(2018), DOI:10.1007/s11696017-0278-5

43. X. Li, J. Tao, J. Zhu, and C. Pan, APL Materials, 5, 074104(2017), DOI:10.1063/1.4977216.

44. Q. Xu and Y. Qin, APL Materials, 5, 074101074101(2017), DOI:10.1063/1.4975772

45. S. Jia, H. Ying, Y. Sun, N. Sun, W. Xu, S. Ning, Int. J. of H. Energy, 42, 18844(2017) DOI:10.1016/j.ijhydene.2017.05.008

46. G. W. Huber, and J. Q. Bond, Cat Chem., 9(9), 1521(2017), DOI: 10.31031/RDMS.2017.01.000502

47. S. Shafiei, and R. A. Ruhul, Energy Policy ,66, 547(2014), DOI: 10.1016/j.enpol.2013.10.064

48. J. A. Seabold and K. S. Choi, J. Am. Chem. Soc.,134, 2186(2012), DOI: 10.1021/ja209001d

49. D. Merki, S. Fierro, H. Vrubel, and X. Hu, Chem. Sci., 2, 1262(2011), DOI:10.1039/C1SC00117E

50. L. A. Stern, L. Feng, F. Song, and X. Hu, Energy Environ. Sci., 8, 2347 (2015), DOI: 10.1039/C5EE01155H

51. D. Wang, T. Hisatomi, T. Takata, C. Pan, M. Katayama, J. Kubota, K. Domen, and Angew. Chem. Int. Ed., 52, 11252(2013), DOI:10.1002/anie.201303693

52. OECD(2011), OECD Green Growth Strategies: Energy. Retrieved March 4,(2017), http://www.oecd.org/greengrowth/greening-energy/49157219

53. A. P. J. Mol, Global Env. Politics, 2(2), 92(2002), DOI:10.1162/15263800260047844

54. A. K. Jorgenson and D. Thomas. Sustainability Science,10(1),149(2015), DOI:10.1007/s11625-0140264-6

NANOTECHNOLOGY FOR ACHIEVING GREEN-ECONOMY 
RASĀYAN $J$. Chem.

Vol. 11 | No. 3 |942 - 950 | July - September | 2018

55. A. K. Jorgenson, and B. Clark, The American J. of Sociology, 118(1), 1(2012), DOI:10.1086/665990

56. A. K. Jorgenson, and B. Clark, Social Sc. Research, 40(1), 226(2011), DOI: 10.1016/j.ssresearch.2010.09.004

57. E. S. Nour, C. O. Chey, M. Willander, and O. Nur, Nanotechnol, 26, 095502, (2015), DOI: 10.1088/0957-4484/26/9/095502

58. O. Mahiana, K. Ali, S. Z. Heris, D. Wen, A. Z. Sahin, S. Wongwises, NanoEnergy, 36, 134(2017), DOI:10.1016/j.nanoen.2017.04.025

59. S. Elhag, Z. H. Ibupoto, X. Liu, O. Nur, and M. Willander, Sensor Actuat B-Chem.,203, 543(2014), DOI: $10.1016 / j . s n b .2014 .07 .028$

60. N. ul Hassan Alvi, Paul E. D. Soto Rodriguez,P. Aseev, V. Jesús Gómez, A. ul Hassan Alvi,W. ul Hassan, M. Willander, R. Nötze, Nano Energy, 13, 291(2015), DOI:10.1016/j.nanoen.2015.02.017

61. M. Poux, P. Cognet, and C. Gourdon (Eds), CRC Press, Boca Raton, FL, (2015).

62. G. Stefanidis, and A. Stankiewicz (Eds), Royal Society of Chemistry Publication, Green Chemistry Series Cambridge, (2016).

63. K. Boodhoo, and A. Harvey, Eds John Wiley \& Sons, Chichester, W Sussex, UK, (2013)

64. M.A. Green, and T. Bein, Nature Mater,14, 559(2015), DOI:10.1038/nmat4301

65. J. You, L. Dou, K. Yoshimura, T. Kato, and K. Ohya, T. Moriarty, K. Emery, C. C. Chen, J. Gao, G .Li, Y. Yang, Nature Communic.,4,1446(2013), DOI: 10.1038/ncomms2411

66. M.B. Gawande, V. D. Bonifacio, and R. Luque, P.S. Branco, R.S. Varma, Chem. Soc. Rev.,42, 5522(2013), DOI: 10.1039/c3cs60025d

67. D. J. Burke, and D. J. Lipomi, Energy Environ Sci.,6, 20153(2013), DOI: 10.1039/C3EE410961

68. P. A. Webley, Adsorption, 20, 225(2014), DOI: 10.1007/s10450-014-9603-2

69. R. Mülhaupt, Macromol Chem. Phys., 214(2), 159(2013), DOI:10.1002/macp.201200439

70. J. Luo, J.H. Im, M.T. Mayer, and M. Schreier, Science, 345, 1593(2014), DOI: $10.1126 /$ science. 1258307

71. C. Jiménez-González, and D.J.C. Constable, John Wiley \& Sons, New York, (2011).

72. P.T. Anastas, and T.C. Williamson, American Chemical Society publications, Washington DC, (1996).

73. Nature Energy, (2017), DOI: 10.1038/nenergy.2017.38

74. Graphene: It's Applications and Uses- Understanding Nano

75. Photovoltaic Ink Could Lead to Easy Solar Panel Manufacture - ArsTechnica

76. H. G. Yoo, M. Byun, C. K. Jeong, and K. J. Lee, Adv. Mater,27, 3982(2015), DOI: 10.1002/adma.201501592

77. Q. Yuan, An-X. Yin, C. Luo, L-D. Sun, Ya-W. Zhang, W-T. Duan, H-C. Liu, and C-H. Yan, J. Am. Chem. Soc.,130(11), 3465(2008), DOI: 10.1021

78. D. Aurbach, J. of Power Sources, 89(2), 206(2000), DOI:10.1016/S0378-7753(00)00431-6

79. M. Gratzel, Inorganic Chem.,44(20), 6841(2005), DOI: 10.1021/ic0508371

80. I. Linkov, Nanomaterials., New York, Springer (2008)

81. D. Vollath, Weinheim, Wiley-VCH.ix,352p,(2008), ISBN:9783527315314 (pbk.)

82. E. Antolini, Energies ,10, 42( 2017), DOI:10.3390/en10010042

83. S. Guo, S. Zhang, L. Wu, S. Sun, Chem. Int. Ed.,51, 11770(2012), DOI:10.1002/anie.201206152

84. C. Cha, S. R. Shin, N. Annabi, M. R. Dokmeci, and A. Khademhosseini, ACS Nano, 7, 2891(2013), DOI: $10.1021 / \mathrm{nn} 401196 \mathrm{a}$

85. S. Tsuruoka, H. Matsumoto, V. Castranova, D.W. Porter, T. Yanagisawa, N. Saito, S. Kobayashi, and M. Endo, Carbon, 95, 302(2015), PMID:26783369 PMCID:PMC4714795

86. H. Yuan, Y. Hou, Z. Wen, and X. Guo, J. Chen, ACS Appl. Mater. Interfaces, 7, 18672(2015), DOI: 10.1021/acsami.5b05144

87. A. Modi, S. Singh, and N. Verma, Int. J. Hydrogen Energy,42, 3271(2017), DOI: 10.1016/j.ijhydene.2016.10.041

88. L.Q. Hoa, H. Yoshikawa, M. Saito, M. Ueda, T. Shibata, and E. Tamiya, Chem. Cat. Chem., 6,135(2014), DOI:10.1002/cctc.201300531

89. N.S. Ismail, L.Q. Hoa, H. Yoshikawa, M. Saito, and E. Tamiya, Electrochim. Acta., 146, 98(2014) 
RASĀYAN J. Chem.

Vol. 11 | No. 3 |942 - 950 | July - September | 2018

90. M. Zhao, Y. Gao, J. Sun, and F. Gao, Anal. Chem., 87, 2615(2015), DOI: 10.1021/acs.analchem.5b00012

91. W. Zheng, H.Y. Zhao, J. X. Zhang, H. M. Zhou, X. X. Xu, Y. F. Zheng, Y. B. Wang, Y. Cheng, and B. Z. Jang, Electrochem. Commun., 12, 869(2010), DOI: 10.1016/j.elecom.2010.04.006

92. F. Gao, L. Viry, M. Maugey, P. Poulin, and N. Mano, Nat. Commun.,1,(2010), DOI: 10.1038/ncomms 1000 .

93. B.C. Kim, I. Lee, S.J. Kwon, Y. Wee, K.Y. Kwon, C. Jeon, H.J. An, H.T. Jung, S. Ha, and J.S. Dordick, Sci. Rep.,7, 40202(2017), DOI: 10.1038/srep40202

94. W. Putzbach, and N. J. Ronkainen, Sensors, 13, 4811(2013), DOI:10.3390/s130404811

95. C.N. Lin, S.Y. Wu, K.S. Lee, P.J. Lin, C.Y. Lin, and J.S. Chang, Int. J. Hydrogen Energy, 32, 802(2007), DOI: 10.1016/j.ijhydene.2006.09.047

96. J. Wei, Z.T. Liu, and X. Zhang, Int. J. Hydrogen Energy, 35, 2949(2010), DOI: 10.1016/j.ijhydene.2009.05.035

97. L. Q. Hoa, Y. Sugano, H. Yoshikawa, M. Saito, and E. Tamiya, Electrochim. Acta.,56, 9875(2011), DOI:10.1016/j.electacta.2011.08.071

98. L. Xu, and F. Armstrong, RSC Adv., 5, 3649(2015), DOI:10.1039/C4RA13565B

99. I. Mazurenko, X. Wang, A. de Poulpiquet, and E. Lojou, Sustain. Energy Fuels., 1, 1475(2017), DOI:10.1039/C7SE00180K

100. S. Zeng, P. Kar, U. Kumar Thakur and K. Shankar, Nanotechnology, 29, 052001(2018), DOI:10.1088/1361-6528/aa9fb1

101. M. Sadeghipari, A. Mashayekhi and S. Mohajerzadeh, Nanotechnology, 29, 055403,(2018), DOI: 10.1088/1361-6528/aaa0e7

102. R. Saidur, K. Y. Leong, H. A. Mohammad, Renew. And Sust., Energy Reviews, 15, 1646(2011), DOI:10.1016/j.rser.2010.11.035

103. A. Lenert, and E. N. Wang, Solar Energy, 86, 253(2012), DOI: 10.1016/j.solener.2011.09.029

104. R. Kumar, R. Savu, R. K. Singh, E. Joanni, D. P. Singh, V. S. Tiwari, A. R. Vaz, E. T. S. G. da Silva, J. R. Maluta, L. T. Kubota, et al., Carbon, 117,137(2017), DOI: 10.1016/j.carbon.2017.02.065

105. B. Shin, H. Shin, C. Kang, Korean Chem. Soc., 33, 4211(2012), DOI: 10.5012/bkcs.2012.33.12.4211.

106. C. Barca, D. Ranava, M. Bauzan, J. H. Ferrasse, M. T. Giudici-Orticoni, A. Soric, Bioresour. Technol., 221, 526(2016), DOI: 10.1016/j.biortech.2016.09.072

107. H. Pang, J. Deng, J. Du, S. Li, J. Li, Y. Ma, and J. Zhang, J. Chen, Dalton Trans., 41, 10175( 2012), DOI:10.1039/C2DT31012K

108. I. Mazurenko, X .Wang., A .de Poulpiquet, E. Lojou, Sustain. Energy Fuels, 1, 1475(2017), DOI: 10.1039/C7SE00180K.

[RJC-3031/2018] 